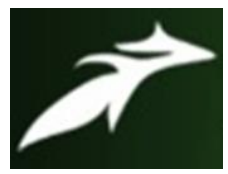

Ritesh Kumar Yadav et al, International Journal of Advances in Agricultural Science and Technology, Vol.8 Issue.9, September-2021, pg. 92-105

\title{
IMPACT OF KVK IN DOUBLING FARMERS INCOME IN SITAPUR DISTRICT OF UTTAR PRADESH
}

\author{
Ritesh Kumar Yadav ${ }^{1}$; Prof. (Dr.) Ms. Jahanara ${ }^{2}$ \\ ${ }^{1}$ M.Sc. Ag. (Agricultural Extension and Communication), SHUATS (Prayagraj) \\ ${ }^{2}$ Head, Department of Agriculture Extension and Communication, SHUATS (Prayagraj) \\ Author's e-mail: riteshyadav23689@gmail.com \\ DOI: 10.47856/ijaast.2021.v08i9.011
}

\begin{abstract}
More than half of Indian population were engaged in agricultural sector but the available technology doesn't ensure food security of the country. Hence, to diffuse new agricultural invention and innovation in the farming community, there arises a need for effective medium for transfer of technology. Thus, KVK bridges the gap between the technology generation and dissemination. The present study was proposed to understand the impact of KVK in doubling farmers income to formulate suitable programmes. For the study, descriptive research design was adopted. 120 respondents from Biswan taluk of Sitapur district of Uttar Pradesh were selected as respondents. Primary data collected from respondents and secondary data from available literatures. The findings revealed that majority of the respondents were middle aged, illiterate, upto 5 members in their family, medium level of annual income, possesses their own land, agriculture as their main occupation, medium level of mass media exposure, office bearer in one organization, high level of extension contact. Meanwhile, more than half of the respondents had reported medium level of impact towards the activities carried out by KVK, beneficiary selection is not unbiased is a major constraint suggested that maximum emphasis should be given on learning by doing.
\end{abstract}

Keywords: KVK, Sitapur, Doubling farmer's income, Agricultural innovation, Impact 


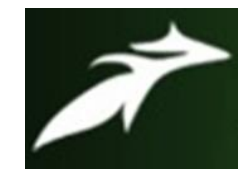

Ritesh Kumar Yadav et al, International Journal of Advances in Agricultural Science and Technology, Vol.8 Issue.9, September-2021, pg. 92-105

ISSN: 2348-1358

Impact Factor: 6.057

NAAS Rating: 3.77

\section{Introduction}

An agricultural invention and innovation continuum in all facets of agriculture and allied activities with its effective diffusion is key to sustainable increase in the productivity with environment sustainability. With half of the workforce engaged in agricultural sector in India, the role of science and technology in agriculture is not only to ensure food security of the country, but also to provide farmers a competitive edge and to maintain affordability of the food items for the public, at large. Modernization of agriculture greatly depends on development of farm and its dissemination. A large number of agricultural technologies are available, but full use of it is not being done in many parts of the country. Thus, there is a big gap in the technology generation and dissemination.

The transfer of farm technology is mainly by the State Department of Agriculture and State Universities through Krishi Vigyan Kendras (KVKs). The KVKs are evolving as the future grass root level institutions for empowering the farming community. KVKs have made dent and have become part of decentralized planning to achieve desired level of growth in agriculture and allied sector. They serve as the light house for rapid agricultural and rural development and act as link between agricultural universities, research institutes and farmers. KVKs play a vital role in conducting On Farm Testing to demonstrate location specific agricultural technologies. Also KVKs conduct demonstrations to prove the potential of crops at farmers' fields. KVKs also conduct need based training programmes for the benefit of farmers and farm women, rural youths.

KVKs are creating awareness about improved agricultural technologies through large number of extension programmes. Critical and quality inputs like seeds, planting materials, organic products, biofertilizers and livestock, piglet and poultry strains are produced by the KVKs and made available to the farmers. The aim of KVK is to reduce the time lag between generation of technology at the research institution and transfer to farmer's fields for increasing 


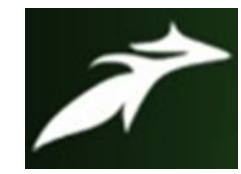

Ritesh Kumar Yadav et al, International Journal of Advances in Agricultural Science and Technology, Vol.8 Issue.9, September-2021, pg. 92-105

ISSN: $2348-1358$

Impact Factor: 6.057

NAAS Rating: 3.77

production, productivity and income from agriculture and allied sectors. "Teaching by doing and learning by doing" are main method of imparting skill training. KVK's have been considered as the most important extension centers to transfer the technology from research station to the farmer's field and therefore, the government has initiated the process of establishing two KVK in each district.

The first KVK in Rajasthan was Bharatiya Krishi Vigyan Kendra, established at Fatehpur Shekhawati of district Sikar in 1976 under the administrative control of M.L. Sukhadia University, Udaipur and 42 more KVKs are working in the state. In each KVK, Senior Scientist cum Head is posted along with six Subject Matter Specialists of Horticulture, Agronomy, Animal Husbandry, Extension Education, Plant Protection and Home Science. Three Programme Assistants and six other ministerial and supporting staff are provided to each KVK making a total of 16 in all. The mandate of KVK is Technology Assessment and Demonstration for its Application and Capacity Development.

In the present context, the agricultural development for income enhancement of the farming community mostly depends on upto date knowledge embedded information led by technological interventions, capacity building and entrepreneurship development .The rural farmers in different disadvantaged areas of our country are facing challenge of knowledge embedded information scarcity and the skill to apply that knowledge in their own situation for enhancing their income. To make the agriculture society more knowledge vibrant and information enriched and income resilient, the KVK led agricultural advisory services for income augmentation may be used as the situation specific solution for the sustainable livelihood of rural peasants . There is need to explore the Role of KVK for doubling farmers income.

Dubey (2008) found that KVK was able to bring about significant changes in socioeconomic status as well as the level of knowledge among different categories of trainees. Training and guidance given to trainees have played prime role in influencing technological 


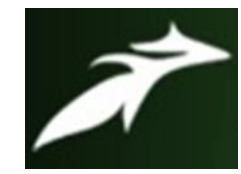

Ritesh Kumar Yadav et al, International Journal of Advances in Agricultural Science and Technology, Vol.8 Issue.9, September-2021, pg. 92-105

ISSN: 2348-1358

Impact Factor: 6.057

NAAS Rating: 3.77

change besides management orientation. The exposure of KVK training programme significantly changed the attitude of farmers in the desired direction which one could easily expect. Ahmad et. al., (2012) stated that KVKs transfer of technology programme had contributed immensely in increasing productivity of farm enterprise but have very little impact on generating gainful employment for the farmers .This clearly reflects that KVKs need to orient its effort for entrepreneurship development among farming community so that farmers /trainees are not only self-employed but also created opportunity for unemployed others.

Gupta and Verma (2013) stated that $77.7 \%$ respondents showed that KVK made an impact in the villages where it functions some activities conducted by KVK like demonstrations , training camps and exhibitions, had great to moderate impact on the respondents. Behera.et.al. (2014) found that KVK, Koraput was playing a vital role in disseminating the improved crop production technology and helps in increasing the crop yield. The technology transferred is also profitable and acceptable to the farming community. Further research need to be focussed on the problems and the constraint for adoption of the technology. Bar (2015) observed that the socioeconomic attributes of the respondents had not much influence in increasing their knowledge level. Hence, KVK have to organise more need based training programmes to enrich knowledge and skill competency of the tribal farmers to adopt the changed practices for more production and income for their sustainable livelihood.

Patelet.al. (2016)stated that government officials should be more acquainted to social system to improve their rapport among farmers and furnish their extension task effectively. Ponnusamy and Devi (2017) found that the adoption of multiple farm enterprises in an integrated manner could ensure a substantial income generation to sustain the livelihood of farmers over the meagre income from self-standing enterprises as revealed from this study. Veeresh and Hosmani (2017) found that after the KVK intervention there was a significant change in socio-economic status of beneficiaries and shift from low and medium socio-economic status to high socioeconomic status .Farmers are benefiting and realizing sufficient income throughout the year with 


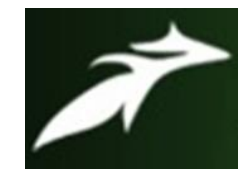

Ritesh Kumar Yadav et al, International Journal of Advances in Agricultural Science and Technology, Vol.8 Issue.9, September-2021, pg. 92-105

ISSN: 2348-1358

Impact Factor: 6.057

NAAS Rating: 3.77

these interventions. Bai (2018) found that extension programme such as OFT/FLD,capacity building and various extension programme conducted by KVK and large-scale demonstration by NGO proved well in dissemination of knowledge about new fodder variety.

\section{Statement of the problem}

Indian agriculture is a complex entrepreneurship system. In one side it is commercially as competitive as international market, however in other side the direct benefit share of farmers in the profit chain is very meagre. In any case, deeply enrooted middlemen system cuts the maximum profit share under unrestricted political influence which pays, sometimes less than the production cost of farmers. The study analyzes the problems of lower farmer income. In this context, the following objectives of the study were framed;

1) To find out the socio-economic and personal characteristics of the respondents.

2) To find out the impact of the activities carried out by KVK.

3) To identify the constraints which hinder income enhancement and suggest possible mitigation.

\section{Methodology}

For the present study, descriptive research design was adopted. In Uttar Pradesh, Sitapur district is purposively selected since it has KVK and farmers were actively participating in Sitapur KVK. In Sitapur district of Uttar Pradesh, Biswan taluk has been selected because there are abundance of Sitapur KVK farmers beneficiaries and these beneficiaries remain mostly attached with Sitapur KVK activities like front line demonstration, vocational training etc. In Biswan taluk of Sitapur district in Uttar Pradesh, 6 villages were selected. The selected villages were Aalampur, Banihar, Belhari, Chelwara, Dewai and Ganeshpur. From each village, 20 farmers were selected. Thus, 120 farmers were selected from the selected six villages and forms the respondents of the study. Primary data were gathered with the help of pre-tested interview schedule from the respondents and secondary data from previous studies, literatures. The data gathered were subjected to statistical analysis and the results were presented. 


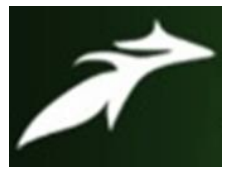

Ritesh Kumar Yadav et al, International Journal of Advances in Agricultural Science and Technology, Vol.8 Issue.9, September-2021, pg. 92-105

ISSN: 2348-1358

Impact Factor: 6.057

NAAS Rating: 3.77

\section{Results and Discussion}

The socio-economic profile of the respondents were studied under various characteristics and the results were presented under table.1.

Table.1. Socio-economic profile of the respondents $(n=120)$

\begin{tabular}{|c|c|c|c|c|}
\hline S. No. & Characteristics & Category & Frequency & Percentage \\
\hline \multirow[t]{3}{*}{1} & \multirow{3}{*}{ Age (in years) } & Young $(<35)$ & 37 & 30.83 \\
\hline & & Middle(36-55) & 54 & 45.00 \\
\hline & & Old $(>55)$ & 29 & 24.17 \\
\hline \multirow[t]{7}{*}{2} & \multirow[t]{7}{*}{ Education } & Illiterate & 32 & 26.67 \\
\hline & & Can read only & 11 & 9.17 \\
\hline & & Can read and write & 17 & 14.17 \\
\hline & & Primary school & 25 & 20.83 \\
\hline & & Middle school & 7 & 5.83 \\
\hline & & High school & 19 & 15.83 \\
\hline & & Graduate & 9 & 7.50 \\
\hline \multirow[t]{3}{*}{3} & \multirow[t]{3}{*}{ Annual Income } & Low & 27 & 22.50 \\
\hline & & Medium & 61 & 50.83 \\
\hline & & High & 32 & 26.67 \\
\hline \multirow[t]{4}{*}{4} & \multirow[t]{4}{*}{ Land holding } & \multicolumn{3}{|l|}{ 1. Homestead land } \\
\hline & & a. Own land & 47 & 39.17 \\
\hline & & b. Share cropping & 32 & 26.67 \\
\hline & & 2. Effective land holding & 41 & 34.17 \\
\hline \multirow[t]{2}{*}{5} & \multirow[t]{2}{*}{ Family size } & Upto 5 members & 79 & 65.83 \\
\hline & & Above 5 members & 41 & 34.17 \\
\hline \multirow[t]{2}{*}{6} & \multirow[t]{2}{*}{ Occupation } & Agriculture & 73 & 60.83 \\
\hline & & Agriculture + labour & 47 & 39.17 \\
\hline \multirow[t]{3}{*}{7} & \multirow{3}{*}{$\begin{array}{l}\text { Mass media } \\
\text { exposure }\end{array}$} & Low & 31 & 25.83 \\
\hline & & Medium & 65 & 54.17 \\
\hline & & High & 24 & 20.00 \\
\hline \multirow[t]{2}{*}{8} & \multirow[t]{2}{*}{ Extension contact } & No membership & 21 & 17.50 \\
\hline & & $\begin{array}{l}\text { Membership in one } \\
\text { organization }\end{array}$ & 25 & 20.83 \\
\hline
\end{tabular}




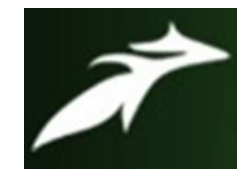

Ritesh Kumar Yadav et al, International Journal of Advances in Agricultural Science and Technology, Vol.8 Issue.9, September-2021, pg. 92-105

ISSN: 2348-1358

Impact Factor: 6.057

NAAS Rating: 3.77

\begin{tabular}{|c|c|c|c|c|}
\hline \multirow{2}{*}{} & & $\begin{array}{l}\text { Membership in more than one } \\
\text { organization }\end{array}$ & 19 & 15.83 \\
\cline { 3 - 5 } & $\begin{array}{l}\text { Office bearer in one } \\
\text { organization }\end{array}$ & 27 & 22.50 \\
\cline { 3 - 5 } & $\begin{array}{l}\text { Office bearer in more than one } \\
\text { organization }\end{array}$ & 23 & 19.17 \\
\cline { 3 - 5 } & $\begin{array}{l}\text { Distinctive feature (MLA and } \\
\text { MP) }\end{array}$ & 5 & 4.17 \\
\hline 9 & Extension contact & Low & 24 & 20.00 \\
\cline { 3 - 5 } & & Medium & 54 & 45.00 \\
\cline { 3 - 5 } & & High & 54.00 \\
\hline
\end{tabular}

From table.1, it can be learnt that majority of the respondents were middle aged (45\%), followed by young age (30.83\%) and old age (24.17\%). Most of the respondents were illiterate (26.67\%), followed by primary (20.83\%), high school (15.83\%), can read and write (14.17\%), can read only $(9.17 \%)$, graduate $(7.50 \%)$ and middle school $(5.83 \%)$. Higher percentage of the respondents had upto 5 members in their family (65.83\%), followed by above 5 members in their family (34.17\%). Half of the respondents had medium level of annual income (50.83\%), followed by high (26.67\%) and low (22.50\%) level of annual income. Most of the respondents had own land (39.17\%), followed by effective land holding (34.17\%) and only 26.67 per cent of the respondents had share cropping.

Most of the respondents had agriculture as their main occupation (60.83\%) and remaining 39.17 per cent of the respondents had agriculture and labor as their main occupation. More than half of the respondents $(54.17 \%)$ had medium level of mass media exposure, followed by 25.83 per cent of respondents had low level and 20 per cent of respondents had high level of mass media exposure. Majority of the respondents were office bearer in one organization $(22.50 \%)$, followed by membership in one organization $(20.83 \%)$, office bearer in more than one organization (19.17\%), no membership (17.50\%), membership in more than one organization $(15.83 \%)$ and distinctive feature (MLA and MP) as (4.17\%). Higher percentage of respondents 


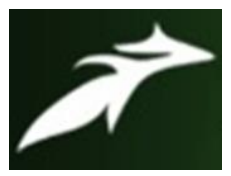

Ritesh Kumar Yadav et al, International Journal of Advances in Agricultural Science and Technology, Vol.8 Issue.9, September-2021, pg. 92-105

ISSN: 2348-1358

Impact Factor: 6.057

NAAS Rating: 3.77

had high level of extension contact (45\%), followed by medium (35\%) and low (20\%) level of extension contact $(20 \%)$.

Impact of activities carried out by KVK were listed and presented in table.2.

Table.2. Impact of activities carried out by KVK

\begin{tabular}{|c|c|c|c|c|c|c|c|}
\hline \multirow[t]{3}{*}{ S. No. } & \multirow[t]{3}{*}{ Activities of KVK } & \multicolumn{6}{|c|}{ Response } \\
\hline & & \multicolumn{2}{|c|}{ Improved } & \multicolumn{2}{|c|}{ Not improved } & \multicolumn{2}{|c|}{ Not sure } \\
\hline & & $F$ & $\%$ & $f$ & $\%$ & $F$ & $\%$ \\
\hline 1 & $\begin{array}{l}\text { Vocational training } \\
\text { provided by KVK }\end{array}$ & 28 & 23.33 & 76 & 63.33 & 16 & 13.33 \\
\hline 2 & $\begin{array}{l}\text { KVK plays vital role in } \\
\text { the transfer of technology }\end{array}$ & 45 & 37.50 & 47 & 39.17 & 28 & 23.33 \\
\hline 3 & $\begin{array}{l}\text { Training provided for } \\
\text { adopting improved } \\
\text { practices }\end{array}$ & 54 & 45.00 & 24 & 20.00 & 42 & 35.00 \\
\hline 4 & Soil testing & 30 & 25.00 & 76 & 63.33 & 14 & 11.67 \\
\hline 5 & $\begin{array}{l}\text { Frontline demonstration } \\
\text { performed by KVK }\end{array}$ & 58 & 48.33 & 7 & 5.84 & 55 & 45.83 \\
\hline 6 & $\begin{array}{l}\text { KVK provides advisory } \\
\text { services about marketing, } \\
\text { climate etc. }\end{array}$ & 45 & 37.50 & 54 & 45.00 & 21 & 17.50 \\
\hline 7 & $\begin{array}{l}\text { KVK creates awareness } \\
\text { about various schemes }\end{array}$ & 33 & 27.50 & 72 & 60.00 & 15 & 12.50 \\
\hline 8 & $\begin{array}{l}\text { Farmer Producer } \\
\text { Organization }\end{array}$ & 34 & 28.33 & 63 & 52.50 & 23 & 19.16 \\
\hline 9 & Biofertilizers & 23 & 19.16 & 91 & 75.83 & 6 & 5.00 \\
\hline 10 & Organic farming & 45 & 37.50 & 56 & 46.67 & 19 & 15.83 \\
\hline 11 & Vermicompost & 36 & 30.00 & 73 & 60.83 & 11 & 9.17 \\
\hline 12 & $\begin{array}{l}\text { Value addition products } \\
\text { and marketing }\end{array}$ & 38 & 31.66 & 54 & 45.00 & 28 & 23.33 \\
\hline 13 & $\begin{array}{l}\text { Proper fertilizer and } \\
\text { nutrient management }\end{array}$ & 39 & 32.50 & 61 & 50.83 & 20 & 16.66 \\
\hline 14 & Kisan Goshti & 52 & 43.33 & 53 & 44.17 & 15 & 12.50 \\
\hline 15 & $\begin{array}{l}\text { Pest and disease } \\
\text { management }\end{array}$ & 45 & 37.50 & 54 & 45.00 & 21 & 17.50 \\
\hline
\end{tabular}




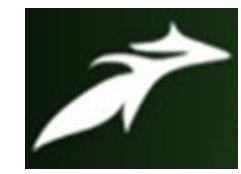

Ritesh Kumar Yadav et al, International Journal of Advances in Agricultural Science and Technology, Vol.8 Issue.9, September-2021, pg. 92-105

ISSN: 2348-1358

Impact Factor: 6.057

NAAS Rating: 3.77

From table.2, it can be interpreted that 23.33 per cent, 63.33 per cent and 13.33 per cent of respondents reported vocational training provided by KVK had improved, not improved and not sure about the impact of KVK activities. 37.50 per cent, 39.17 per cent and 23.33 per cent of respondents reported KVK plays vital role in the transfer of technology had improved, not improved and not sure about the impact of KVK activities. 45 per cent, 20 per cent and 35 per cent of respondents reported training provided for adopting improved practices had improved, not improved and not sure about the impact of KVK activities. 25 per cent, 63.33 per cent and 11.67 per cent of respondents reported soil testing had improved, not improved and not sure about the impact of KVK activities.

Meanwhile, 48.33 per cent, 5.84 per cent and 45.83 per cent of respondents reported frontline demonstration performed by KVK had improved, not improved and not sure about the impact of KVK activities. 37.50 per cent, 45 per cent and 17.50 per cent of respondents reported KVK provides advisory services about marketing, climate, etc. had improved, not improved and not sure about the impact of KVK activities. 27.50 per cent, 60 per cent and 12.50 per cent of respondents reported KVK creates awareness about various schemes had improved, not improved and not sure about the impact of KVK activities. 28.33 per cent, 52.50 per cent and 19.16 per cent of respondents reported Farmer Producer Organization had improved, not improved and not sure about the impact of KVK activities.

Similarly, 19.16 per cent, 75.83 per cent and 5.00 per cent of respondents reported biofertilizers had improved, not improved and not sure about the impact of KVK activities. 37.50 per cent, 46.67 per cent and 15.83 per cent of respondents reported organic farming had improved, not improved and not sure about the impact of KVK activities. 30 per cent, 60.83 per cent and 9.17 per cent of respondents reported vermicompost had improved, not improved and not sure about the impact of KVK activities. 31.67 per cent, 45.00 per cent and 23.33 per cent of respondents reported value addition products and marketing had improved, not improved and not sure about the impact of KVK activities. 


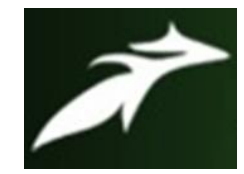

Ritesh Kumar Yadav et al, International Journal of Advances in Agricultural Science and Technology, Vol.8 Issue.9, September-2021, pg. 92-105

ISSN: 2348-1358 Impact Factor: 6.057 NAAS Rating: 3.77

Eventually, 32.50 per cent, 50.83 per cent and 16.67 per cent of respondents reported proper fertilizer and nutrient management had improved, not improved and not sure about the impact of KVK activities. 43.33 per cent, 44.17 per cent and 12.50 per cent of respondents reported Kisan Goshti had improved, not improved and not sure about the impact of KVK activities. 37.50 per cent, 45.00 per cent and 17.50 per cent of respondents reported pest and disease management had improved, not improved and not sure about the impact of KVK activities.

The overall impact of activities carried out by KVK was categorized and presented in table.3.

Table.3. Overall impact of activities carried out by KVK

$(\mathbf{n}=\mathbf{1 2 0})$

\begin{tabular}{|c|c|c|c|}
\hline S. No. & Category & Frequency & Per cent \\
\hline 1 & Low & 21 & 17.50 \\
\hline 2 & Medium & 62 & 51.67 \\
\hline 3 & High & 37 & 30.83 \\
\hline \multicolumn{2}{|c|}{ Total } & 120 & 100.00 \\
\hline
\end{tabular}

From table.3, it can be seen that more than half of the respondents had reported medium level of impact (51.67\%), followed by high (30.83\%) and low (17.50\%) level of impact towards the activities carried out by KVK.

The constraints experienced by the respondents which hinder income enhancement were listed and presented in table.4. 


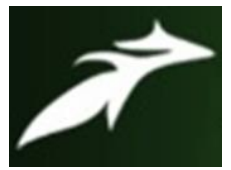

Ritesh Kumar Yadav et al, International Journal of Advances in Agricultural Science and Technology, Vol.8 Issue.9, September-2021, pg. 92-105

ISSN: 2348-1358

Impact Factor: 6.057

NAAS Rating: 3.77

Table.4. Constraints that hinder income enhancement

$(\mathrm{n}=120 *)$

\begin{tabular}{|c|l|c|c|c|}
\hline S. No. & \multicolumn{1}{|c|}{ Constraints } & \multicolumn{3}{c|}{ Response } \\
\cline { 3 - 4 } & & Frequency & Percentage & Ranking \\
\hline 1 & Duration of training is not appropriate. & 45 & 37.50 & VII \\
\hline 2 & $\begin{array}{l}\text { Course content of training are not related } \\
\text { too much with felt needs }\end{array}$ & 54 & 45.00 & V \\
\hline 3 & The timings of the training is not suitable & 89 & 74.17 & II \\
\hline 4 & Less provision for learning by doing & 29 & 24.17 & VIII \\
\hline 5 & $\begin{array}{l}\text { Over loaded information (too much } \\
\text { information is short time) }\end{array}$ & 48 & 40.00 & VI \\
\hline 6 & $\begin{array}{l}\text { Absence of field visit on successful } \\
\text { demonstration during training }\end{array}$ & 86 & 71.67 & III \\
\hline 7 & $\begin{array}{l}\text { Less time for group discussion } \\
\text { Improper use of A.V aids }\end{array}$ & 21 & 17.50 & IX \\
\hline 9 & $\begin{array}{l}\text { Location of FLD and OFT are not well } \\
\text { thought of. }\end{array}$ & 72 & 60.00 & IV \\
\hline 10 & Selection of beneficiary is not unbiased. & 116 & 96.67 & I \\
\hline
\end{tabular}

(*-Multiple responses recorded)

From table.4, it can be seen that beneficiary selection is not unbiased (96.67\%) secured first rank, followed by timing of training is not suitable (74.17\%), absence of filed visit on successful demonstration during training (71.67\%). Location of FLD and OFT are not well thought of (60\%), course content of training are not related too much with felt needs (45\%), over loaded information (40\%), duration of training is not appropriate (37.50\%), less provision for learning by doing (24.17\%), less time for group discussion (17.50\%) and improper use of audio visual aids $(12.50 \%)$ secured $2^{\text {nd }}$ rank, $3^{\text {rd }}$ rank, $4^{\text {th }}$ rank, $5^{\text {th }}$ rank, $6^{\text {th }}$ rank, $7^{\text {th }}$ rank, $8^{\text {th }}$ rank, $9^{\text {th }}$ rank and $10^{\text {th }}$ rank simultaneously.

The suggestions suggested by the respondents were identified and presented in table.5. 


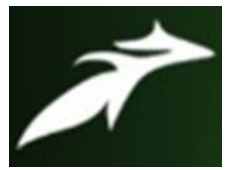

Ritesh Kumar Yadav et al, International Journal of Advances in Agricultural Science and Technology, Vol.8 Issue.9, September-2021, pg. 92-105

ISSN: 2348-1358

Impact Factor: 6.057

NAAS Rating: 3.77

Table.5. Suggestions given by the respondents to overcome the constraints

$(\mathbf{n}=120 *)$

\begin{tabular}{|c|l|c|c|c|}
\hline S. No. & \multicolumn{1}{|c|}{ Suggestions } & \multicolumn{3}{|c|}{ Response } \\
\cline { 3 - 5 } & & Frequency & Percentage & Ranking \\
\hline 1 & $\begin{array}{l}\text { Training should be organized at farmer's } \\
\text { field when farmers are not engaged in } \\
\text { farm operations }\end{array}$ & 63 & 52.50 & III \\
\hline 2 & Variety of teaching aids shall be used. & 11 & 9.17 & X \\
\hline 3 & $\begin{array}{l}\text { Maximum emphasis should be given on } \\
\text { learning by doing }\end{array}$ & 91 & 75.83 & I \\
\hline 4 & $\begin{array}{l}\text { Training should be imparted in local } \\
\text { spoken language }\end{array}$ & 54 & 45.00 & IV \\
\hline 5 & $\begin{array}{l}\text { Training should be related to felt needs } \\
\text { of the farmers }\end{array}$ & 73 & 60.83 & II \\
\hline 6 & $\begin{array}{l}\text { Continue rapport be maintained with } \\
\text { farmers }\end{array}$ & 29 & 24.17 & VII \\
\hline 7 & $\begin{array}{l}\text { Transport and communication facilities } \\
\text { should be proper }\end{array}$ & 38 & 31.66 & VI \\
\hline 8 & $\begin{array}{l}\text { Related literature should be pre } \\
\text { distributed among the trainees }\end{array}$ & 21 & 17.50 & VIII \\
\hline 9 & $\begin{array}{l}\text { Assessment of training shall be done } \\
\text { before concluding session. }\end{array}$ & 15 & 12.50 & IX \\
\hline 10 & $\begin{array}{l}\text { Stipend should be increased for active } \\
\text { participation }\end{array}$ & 45 & 37.50 & V \\
\hline
\end{tabular}

(*-Multiple responses recorded)

From table.5, it can be interpreted that most of the farmers suggested that maximum emphasis should be given on learning by doing $(75.83 \%)$ secured $1^{\text {st }}$ rank, followed by training should be related to felt needs of the farmers $(60.83 \%)$, training should be organized at farmer's field when farmers are not engaged in farm operations (52.50\%), training should be imparted in local spoken language (45\%), stipend should be increased for active participation (37.50\%), transport and communication facilities should be pre-distributed among the trainees (17.50\%), assessment of training shall be done before concluding session (12.50\%) and variety of teaching 


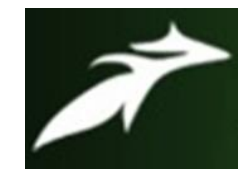

Ritesh Kumar Yadav et al, International Journal of Advances in Agricultural Science and Technology, Vol.8 Issue.9, September-2021, pg. 92-105

ISSN: 2348-1358

Impact Factor: 6.057

NAAS Rating: 3.77

aids shall be used $(9.17 \%)$ secured $2^{\text {nd }}$ rank, $3^{\text {rd }}$ rank, $4^{\text {th }}$ rank, $5^{\text {th }}$ rank, $6^{\text {th }}$ rank, $7^{\text {th }}$ rank, $8^{\text {th }}$ rank, $9^{\text {th }}$ rank and $10^{\text {th }}$ rank respectively.

\section{Conclusion}

From the present study, it can be concluded that majority of the respondents were middle aged, illiterate, up to 5 members in their family, medium level of annual income, possesses their own land, agriculture as their main occupation, medium level of mass media exposure, office bearer in one organization, high level of extension contact. Meanwhile, more than half of the respondents had reported medium level of impact towards the activities carried out by KVK. Thus, beneficiary selection is not unbiased is a major constraint and most of the respondents suggested that maximum emphasis should be given on learning by doing. Eventually, it was implied that in order to increase efficiency of extension service delivery, reduce repetitions and for better utilization of scarce resources, effective convergence and better linkage between different organizations at all levels requires careful harmonization of work plans that will require support of the extension services to succeed.

\section{References}

- Ahmad, Nafees, Singh, S.P, and Parihar ,P.(2012) Farmers' assessment of KVK Training Programme .Indian Research journal of Extension Education .Special Issue.1:186-188.

- Bai,kamala S., Nagraj,K.H., Ali,Mazhar Syed,Rangnath,S.C. and Rayudu ,B.T.(2018). Farmer's Perception on Economics and Varietal Performance of High Yielding Multicut Napier Fodder - DNH-6:Result of Front Line Demonstration in Ramanagar District, Karnataka, India. International Journal of Current Microbiology and Applied Science. 7(6):1947-1954

- Bar , Narayan.(2015).Impact of KVK in transferring Knowledge to Tribal Farmers on Farm Activities .Global Journal of Science Frontier Research:D agriculture and Veterinary.15(3):28-34. 


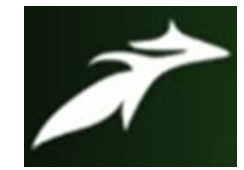

Ritesh Kumar Yadav et al, International Journal of Advances in Agricultural Science and Technology, Vol.8 Issue.9, September-2021, pg. 92-105

ISSN: 2348-1358

Impact Factor: 6.057

NAAS Rating: 3.77

- Behera,S.K. ,Maharana,J.R. and Acharya ,P.(2014).Transfer of Technology through Krishi Vigyan Kendra for the Tribal Farmers in Hilly Areas of Koraput District .Indian Journal of Hill Farming .27(2):34-37.

- Dubey,A.K., Srivastava,J.P. and Sharma, V.K.(2008).Attitude of the Respondents towards KVK Training Programme, Indian Research Journal of Extension Education .8(2\&3):78-80.

- Gupta, Shobhana and Verma ,Shilpi.(2013).Impact of KVK on Knowledge level of farm women.The Journal of Rural and Agricultural Research .13(2):87-89.

- Patel,R.K. , Kadian, K.S. and Singh,N.(2016). Constraints experienced by Krishi Vigyan Kendra (KVK) trainee and non -trainee dairy farmers in training. Journal of Livestock Science .7:84-88.

- Ponnusamy,K. and Devi,Kousalya.(2017).Impact of Integrated Farming System Approach on Doubling Farmers' Income .Agricultural Economics Research Review.30(conference number):233-240.

- Veeresh,Kaadli and Hosmani,S.B.(2017).Impact of KVK Interventions on Socioeconomic status of Beneficiary households in Dharwad District. International Journal of Agriculture, Environment and Biotechnology.10(5):615-623. 